\title{
A case of placental chorioangioma
}

\section{Vasanthi D., Nagashree U.*, Sreepriya Sundaram}

Department of Obstetrics and Gynecology, Apollo Womens Hospital, Shafi Mohammed Road, Thousand Light, Chennai, Tamil Nadu, India

Received: 09 July 2020

Accepted: 05 August 2020

\section{*Correspondence:}

Dr. Nagashree U.,

E-mail: dr.nagashree@yahoo.com

Copyright: (c) the author(s), publisher and licensee Medip Academy. This is an open-access article distributed under the terms of the Creative Commons Attribution Non-Commercial License, which permits unrestricted non-commercial use, distribution, and reproduction in any medium, provided the original work is properly cited.

\begin{abstract}
Chorioangioma is a benign tumor of placenta, incidence being 1 in 100 cases. It is mostly diagnosed ultrasonically in the second trimester of pregnancy. Large chorioangiomas render a challenge to obstetricians due to the foeto maternal complications and adverse outcomes. Here by authors present a case report of large chorioangioma with no fetomaternal complications but just for awareness of the importance of early diagnosis and to look out for possible adverse effects on mother and foetus.
\end{abstract}

Keywords: Benign tumor, Chorioangioma, Doppler, Poly hydramnios

\section{INTRODUCTION}

Placental chorioangioma is the most common tumor of placenta. Incidence is 1 in 100 placentas; seen more frequently in multiple pregnancies and in female babies. ${ }^{1}$

It's mostly attributed to capillary dys vasculogenesis. Large chorioangiomas can cause maternal and foetal complications while the smaller ones are asymptomatic. Importance of early diagnosis, follow-up, antenatal surveillance and timing of delivery have to be individualized.

\section{CASE REPORT}

An unbooked 26-year-old primigravida of 28 weeks gestation with a known chorangioma of placenta diagnosed at 20 weeks was referred to the study hospital for tertiary care.

She had a spontaneous conception, $\mathrm{H} / \mathrm{O}$ regular menstrual cycles. She had no comorbidities-she had subclinical hypothyroidism in pregnancy for which she is on medication; no other significant family history could be elicited. Only H/O subchorionic haemorrhage at 11+ weeks gestation on ultrasound.

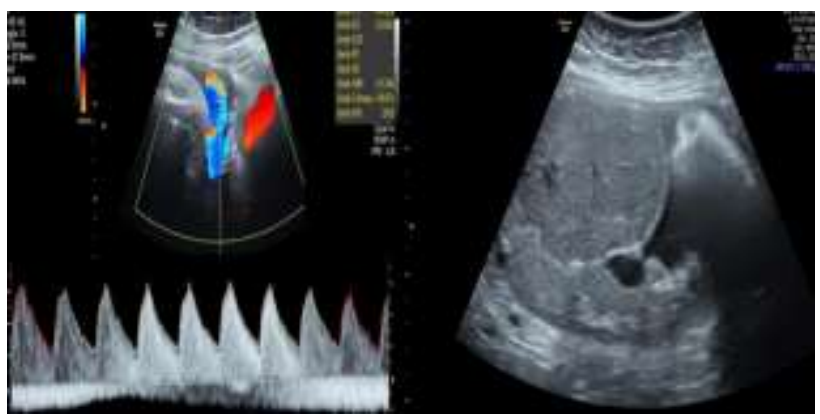

Figure 1: Placental chorioangioma with Doppler.

A 28 weeks growth scan at study centre showed a hypoechoic mass lesion of $5.4 \times 5.1 \mathrm{~cm}$ seen arising from the placenta on foetal side close to cord insertion. Umbilical and Middle cerebral artery Doppler was normal and estimated foetal weight was $1092 \mathrm{gm}$ which corresponded to the period of gestation. Serial follow up through scan was done every 2 weeks to monitor growth and liquor with dopplers. 


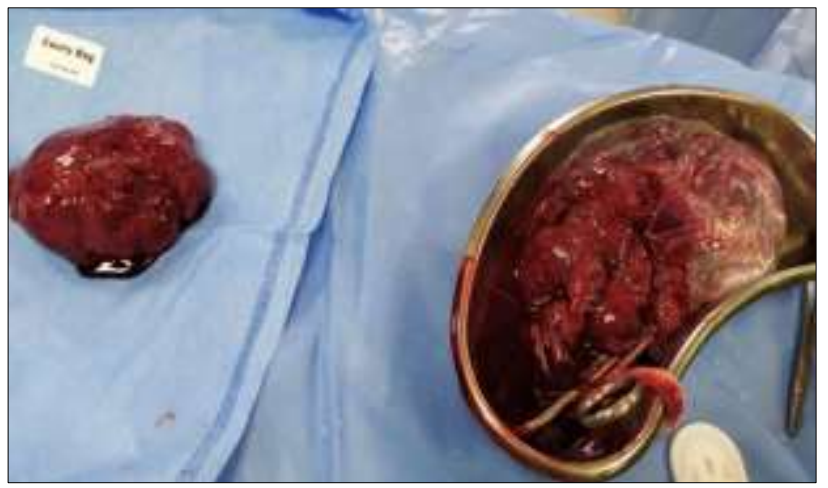

Figure 2: Placental chorioangioma.

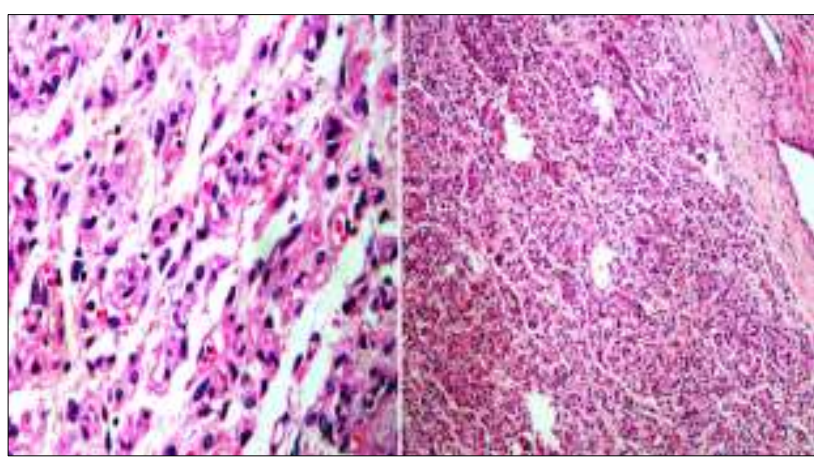

Figure 3: Pic 1 (40x) and 4 (10x) (H and E): section of a mass lesion composed of proliferating capillary sized blood vessels lined by endothelial cells.

A 34 weeks scan showed a placental mass of $8.1 \times 5.9 \mathrm{~cm}$ seen along the upper edge of the placenta revealing significant vascularity with venous and arterial flow. Umbilical and Middle cerebral artery Doppler was normal, AFI was $15.1 \mathrm{~cm}$ and estimated foetal weight was $1853 \mathrm{gm}$; which was small for gestational age. She was advised high protein diet, monitoring of fetal kick counts daily, regular Blood pressure monitoring with immediate reporting in case of breathlessness or pain abdomen. Possibility of preterm labour was explained and she was given Inj. Betamethasone $12 \mathrm{mg}$ two doses 24 hours apart. At 37 weeks gestation - the size of the placental tumor was the same with foetal weight of 2.4 $\mathrm{kg} \pm 200 \mathrm{gm}$. She was planned for elective LSCS at 38 weeks gestation in view of large placental tumor.

She delivered an alive girl baby of $2.6 \mathrm{~kg}$ with a cord around the neck. Placenta with a large tumor was removed and sent for HPE. Postpartum period was uneventful.

HPE revealed chorioangioma of placenta. Chorioamniotic membrane and cord are unremarkable.

\section{DISCUSSION}

Placental chorioangiomas are benign hamartomatous placental growths comprising vascular tissue reported in approximately $1 \%$ cases. $^{2}$ Large chorioangiomas $>5 \mathrm{~cm}$ has been reported to occur at a rate of 1:3500 to 1:16000 births. $^{3}$ They have no malignant potential. Three histological types of chorioangiomas have been described.

Angiomatous (capillary), cellular and degenerative with angiomatous as the most common type.

\section{Maternal complications}

Maternal complications were polyhydramnios, preterm labour, toxaemia of pregnancy and abruption

\section{Foetal complications}

Foetal complications were congenital abnormalities, foetal hemolytic anaemia, foetal thrombocytopenia, foetal cardiomegaly.

Associated anomalies: An association has been noted between chorioangioma and the following

Fetal hemangiomata, twinning, single umblical artery, velamentous insertion, fetal hydrops (worse prognosis).

\section{Theories for polyhydramnios}

a. Transudation of fluid caused by mechanical obstruction of blood flow by the tumor near the cord insertion.

b. Increased transudation of fluid due to large vascular surface area.

c. Functional insufficiency of placenta secondary to bypassing foetal circulation via shunt mechanism into tumor vascular bed.

Perinatal mortality has been reported in about $30-40 \%$ cases. Foetal cardiomegaly could be secondary to high cardiac output from AV shunting leading to heart failure. Vascularity of the tumor may be more important than the size in development of polyhydramnios. Large chorioangiomas $>5 \mathrm{~cm}$ particularly when rapid growing is associated with negative clinical impact. ${ }^{4,5}$

\section{Diagnosis}

Feto maternal haemorrhage across tumor capillaries leads to elevated AFP levels in maternal blood and maternal hemolysis.

Ultrasound with colour doppler imaging confirms the diagnosis. $^{6}$

MRI findings could be heterogenous mass with high T2 signal intensity appearance similar to hemangioma.

Fetal anemia is assessed by middle cerebral artery -peak systolic velocity and foetal heart strain by assessing cardiomegaly and ductus venosus pulsatility index..$^{7,8}$ 


\section{Decision to deliver patients based on criteria}

Uncomplicated cases: Irrespective of the size of tumor, decision regarding mode of delivery can be taken at term gestation.

Complicated cases: Elective/emergency surgery can be planned based on the fetal viability and complications.

IUGR babies: Serial follow ups are needed in these cases. If ductus venosus pulsatility index DV-PI above $95^{\text {th }}$ percentile before 32 weeks, if reversed umbilical artery end diastolic flow from 32 weeks, if absent umbilical artery end diastolic flow from 34 weeks and decision for delivery to be taken.

Suspicious or non-reactive CTG changes: Fetal heart rate short term variability $<2.5^{\text {th }}$ percentile, significant deterioration of foetal biophysical profile $(<6 / 10)$.

\section{Differential diagnosis}

Differential diagnosis were partial hydatidiform mole, placental hematoma, degenerated myoma uteri.

\section{Management}

Proper timing of labour is controversial and depends on fetomaternal complications. The more vascular the tumor, the worse the perinatal outcome. In this case which had decreased tumor vascularity, minimal complications were seen. Rapid growth of vascular tumors has been reported in the second trimester.

Several fetal therapies have been attempted with variable results.

Supportive measures include serial fetal intrauterine transfusions, amnioreduction through therapeutic amniocentesis, maternal transplacental pharmacotherapy with Indomethacin.

Definitive endoscopic surgical devascularization (ligation /clipping fetoscopic laser ablation, embolization, chemo sclerosis with absolute alcohol injection) and radiofrequency ablation of tumor vessels can be performed.

\section{Follow-up}

Small tumors usually monitored with ultrasound every 68 weeks; large tumors require serial ultrasound 1-2 weeks. ${ }^{9}$
In case of IUGR and fetal complications- monitoring with doppler imaging and CTG as OP basis is advisable.

\section{CONCLUSION}

Importance of early diagnosis and individualized assessment is the key point. Serial ultrasound and Doppler, follow-up in case of foetal complications every 2 weeks is advisable. High foetal death in these cases warrants institutional and timely delivery.

Funding: No funding sources

Conflict of interest: None declared

Ethical approval: The study was approved by the Institutional Ethics Committee

\section{REFERENCES}

1. Guschmann M, Henrich W, Dudenhausen JW. Chorioangiomas-new insights into a well knownproblem II. An immunohistochemical investigation of 136 cases. J Perinat Med. 2003;31:170-5.

2. Ulkumen BA, Pala HG, Nese N, Baytur Y. Prenatal diagnosis and fetomaternal outcomes of two cases with placental chorioangioma. Case Rep Obstet Gynecol. 2013;2013:926473.

3. Esen UI, Orife SU, Pollard K. Placental chorioangioma: a case report and literature review. Br J Clin Pract. 1997;51(3)181-2.

4. Kodandapani S, Shreshta A, Ramkumar V, Rao L. Chorioangioma of placenta: a rare placental cause for adverse fetaloutcome. Case Rep Obstet Gynecol. 2012;2012:913878.

5. Kirkpatrick AD, Podberesky DJ, Gray AE, Mcdermott JH. Placental chorioangioma. Radiographcs. 2007;27(4):1187-90.

6. Jauniaux E, Ogle R. Color Doppler imaging in the diagnosis and management of chorioangiomas. Ultrasound Obstet Gynecol. 2000;15:463-7.

7. Mari G. Non-invasive diagnosis by doppler ultrasonography of fetal anemia due to maternal red cell alloimmunization. N Engl J Med. 2000;342:914.

8. Awadh DM, Prefump F, Bland JM, Carvalho JS. Assessment of the intra-observer variability in the measurement of fetal cardiothoracic ratio using ellipse and diameter methods. Ultrasound Obstet Gynecol. 2006;28:53-6.

9. Harris RD, Cho C, Wel WA. Sonography of the placenta with emphasis on pathological correlation. Semin Ultrasound CT MR. 1996;17(1):66-89.

Cite this article as: Vasanthi D, Nagashree U, Sundaram S. A case of placental chorioangioma. Int J Reprod Contracept Obstet Gynecol 2020;9:3892-4. 